\title{
CHALLENGES TO THE SPECIAL RELATIONSHIP BETWEEN THE UNITED STATES AND THE UNITED KINGDOM THROUGH THE PRISM OF THE ACTIONS OF PRESIDENT JOE BIDEN AND PRIME MINISTER BORIS JOHNSON
}

\begin{abstract}
The United States and the United Kingdom have special political, economic, military and cultural relations. The new American administration is restoring priority to multilateralism and old alliances, and the British authorities have announced an expansion of international engagement. The effects of the COVID-19 pandemic, the fight against climate change, the growth of China's influence, and threats to cybersecurity are the biggest international challenges in the view of both states. The US and the UK urge other states to jointly take responsibility and work out solutions to the world's most crucial problems. The United Kingdom left the European Union in January 2020 and, in line with the rhetoric of the government, it regained a sovereign foreign policy. USUK relations could deepen but new troubles appeared, for example the need to negotiate a new trade deal. However, the differences between Joe Biden and Boris Johnson are less important in the face of common interests, as evidenced by the signing of a new Atlantic Charter by both leaders in June 2021 or increasing joint engagement in the Indo-Pacific region.
\end{abstract}

Keywords: United States, United Kingdom, special relationship, Joe Biden, Boris Johnson

Contact: z.ptaszynska@student.uw.edu.pl 


\section{INTRODUCTION}

The author aims to identify the most important challenges to the special relationship between the United States and the United Kingdom during the presidency of Joe Biden, and to formulate conclusions on a possible path for these relations to develop under the current US administration. The topic seems important because of the shift of American foreign policy towards old alliances and multilateralism after the inauguration of the new presidency, and Joe Biden's negative perception of the departure of the United Kingdom from the European Union, which determines the UK's current foreign policy. The British authorities announce the doctrine of Global Britain, and, as politicians and researchers emphasize, the United States and the United Kingdom, which are connected with special political, economic and military ties, need each other to better implement their foreign policy goals. The actions of President Joe Biden and Prime Minister Boris Johnson are an important context of the research, as they are the creators of their states' foreign policy and the personal contacts of US and UK leaders have always been one of the foundations of the strength of this special relationship.

The methodology of the work was based on the analysis of discourse: the author primarily analyzes the statements (speeches, statements in interviews) of President Biden and Prime Minister Johnson, which relate to the priorities in the relations of these states. The additional method was the analysis of primary sources (strategic documents, reports of government centers) and secondary sources (press articles).

The first part of the article invokes and explains the notion of the special relationship between the United States and the United Kingdom and the positions of President Joe Biden and Prime Minister Boris Johnson on the importance of British-American relations as well as each other as people and politicians. In the second part of the article, the author identifies the most important common interests and activities in the US-UK relations during the presidency of Joe Biden. The positions of leaders on issues important for cooperation between states are collected - these are: political and economic reconstruction of the world after the COVID-19 pandemic, combating the effects of climate change, the growing influence of the People's Republic of China, and the cooperation of intelligence and in the field of cybersecurity. The third part of the article is devoted to issues difficult for US-British relations during the presidency of Joe Biden. These are primarily the effects of the United Kingdom leaving the Euro- 
pean Union, which is related to, inter alia, the issue of preparing a new trade agreement with the US. The reduction of foreign aid, as proposed by Boris Johnson, is also important, as Joe Biden increases its financing. The last part of the article is a synthesis of the points of contact and contradictions in the current US-UK relations and an attempt to forecast their development under Joe Biden presidency.

\section{THE NOTION OF THE SPECIAL RELATIONSHIP AND THEIR PRIORITIZATION IN BOTH STATES}

The United States and the United Kingdom have special political, economic, military and cultural relations. This term was popularized in 1946 by the British Prime Minister Winston Churchill, and it was intended to define the unique nature of the alliance of the former metropolis and its former colony which became a superpower. States are linked by linguistic and cultural ties, a similar understanding of many key political values and belonging to international structures that are decisive for the creation and maintenance of the international order. They are permanent members of the UN Security Council, the body responsible for international peace and security, belong to the $\mathrm{G} 7$ and G20, are the founding states and one of the most important members of the North Atlantic Alliance. They support each other's international activity very often and were allies during many conflicts in the 20th and 21 st centuries. Importantly, their level of economic and technological exchange or intelligence cooperation can in many respects be described as preferential and even unprecedented in terms of relations between world powers. Essential elements of this special relationship are the personal, cordial contacts of American leaders with British prime ministers and with the head of state, the Queen, characterized by frequent visits, both public and private.

Boris Johnson prefers not to use the term special relationship. According to him, it weakens the importance of the United Kingdom and he prefers terms that more clearly suggest equality of the allies. It is even more important after the withdrawal of the United Kingdom from the European Union and the implementation of the rhetoric of regaining sovereignty and strengthening the global position of the UK. Johnson describes the relationship with the United States as "indestructible", "deep" and "meaningful" (BBC News 2021, 1:07-1:12). Although Prime Minister Johnson made his remarks to the American President, the US leader and his associates continued to use the term special relationship in reports or at press conferences. As stated in "The Integrated Review of Security, Defense, Development and Foreign Policy" presented by 
the British government in March 2021, "our influence will be amplified by stronger alliances and wider partnerships - none more valuable to British citizens than our relationship with the United States" (UK Cabinet Office 2021: 6). Joe Biden emphasized in The Interim National Security Strategic Guidance the crucial importance of the United Kingdom in building a common transatlantic agenda "on the defining issues of our time." (The White House 2021).

The leaders have polarizing political backgrounds - Boris Johnson leads the Conservative Party cabinet, while Joe Biden comes from the liberal Democratic Party. The current US leader in 2019 called the British Prime Minister a "physical and emotional clone" of Donald Trump, emphasizing the bold tone of his statements and their populist messages (Frazin: 2019). However, it can be concluded that such words were needed for internal use and were not intended to discredit such an important partner as the United Kingdom is for the United States. Boris Johnson was one of the first world leaders to congratulate Joe Biden on winning the presidential election in November 2020, even though President Donald Trump did not recognize the election result. Following the G7 Summit in Cornwall, Johnson spoke enthusiastically about Biden being a "breath of fresh air", and emphasized shared belief in a transatlantic alliance, strong democracy, human rights and a rulesbased international order, and prioritization of the fight against climate change (BBC News 2021, 0: 36-1: 05). In February 2021, he stated that "America is unreservedly back as leader of the free world and that is a fantastic thing." (Prime Minister's Office 2021 ["Prime Minister's speech...”]).

The new US leader has met Prime Minister Boris Johnson three times so far ${ }^{1}$. Biden's first foreign visit as president took place in Cornwall, UK, at the G7 summit that began on June 11, 2021. The talks focused on the international consequences of the COVID-19 pandemic, climate change, financing infrastructure in developing states and the situation in Afghanistan. The US and UK leaders signed the new Atlantic Charter referring to a document signed by President Franklin D. Roosevelt and Prime Minister Winston Churchill in 1941. As President Biden explained, the new document is "a statement of first principles, a promise that the United Kingdom and United States would meet the challenges of their age and would meet it together." (Administration of Joseph R. Biden, Jr. 2021). The second meeting took place right after the G7 summit, on June 14 in Brussels at the NATO summit. For the third time, the leaders met at the White House following the opening of the 76th session of the UN General Assembly. The place

1) As of September 23, 2021. 
itself emphasizes the importance of the meeting for the Americans. The leaders were enthusiastic, though when asked by a journalist about a new trade deal with the United Kingdom, Biden responded slightly less enthusiastically that "we'll have to work that through." (Fox News 2021, 6: 45-6: 52).

\section{THE MOST IMPORTANT COMMON INTERESTS AND ACTIVITIES IN US-UK RELATIONS}

\section{Consolidating efforts in the international fight against the COVID-19 pandemic}

Boris Johnson assures that the US allies across the Atlantic can and are ready to share the burden of solving the world's most difficult problems (Prime Minister's Office 2021 ["Prime Minister's speech..."]). The Prime Minister eagerly emphasizes the strategy of Global Britain, i.e. strengthening the visibility of the United Kingdom on the international arena and involvement in various parts of the world, in various areas of international relations. These kinds of superpower ambitions of the United Kingdom are not characterized by the will to compete with the United States, but rather to expand the ability to at least partially keep pace with the Americans, to be an even more attractive partner, but also to increase its strengths and self-worth.

Prime Minister Johnson considers the challenge of combating COVID-19 and the political and economic recovery of the world after the pandemic to be an important test of leadership. Similarly, Joe Biden, who took over the pandemic cases after President Trump, wants to show American solidarity with states around the world, regardless of daily differences and without business intentions. In the new Atlantic Charter, the US and the UK have securitized health. The states pledged to continue working together to strengthen health systems and help other states do the same (The White House 2021 ["The new..."]). At the end of May 2021, the President presented a budget proposal that included a significant increase in financing foreign aid. Adopted by Congress and taking into account the President's proposal, the budget for 2022 includes $\$ 10.1$ billion for global health programs, including about $\$ 1$ billion for global health safety programs and support to contain the COVID-19 pandemic (The White House 2021 ["Budget..."] : 22). In turn, at last year's (2020) UN General Assembly, the British Prime Minister proposed a fivepoint plan to protect the world against future epidemics. In February 2021 Johnson compared creating a system of protection against further pathogens with uniting against military threats (Prime Minister's Office 
2021 ["Prime Minister's speech..."]). Importantly, the United Kingdom is one of the founders and one of the largest donors of COVAX, a global alliance to supply COVID-19 vaccines to developing states. Of course, the crucial matter for both states is to resolve the crisis at home, but both leaders are aware that, especially in the era of globalization and interdependence, the situation in the US and the UK is related to that of other states. In addition, showing generosity and selflessness can strengthen their image in the international arena.

\section{International fight against the effects of climate change}

Joe Biden and Boris Johnson have a similar understanding of security, as they deviate from its traditional understanding and see the expanding spectrum of threats. They prioritize the fight against climate change and underline the need for closer consolidation of international efforts on this issue. Particularly noteworthy is the fact that the United States acceded to the Paris Agreement again, which was one of the first decisions of the new President. The UK, in turn, is implementing the Green Industrial Revolution, and Boris Johnson said he hoped other states would follow the British footsteps (Prime Minister's Office 2021 ["PM speech..."]). The US and UK leaders collaborated on a virtual climate summit in April 2021, hosted by the US President, which was to be the prelude to the UN climate summit (COP26) in Glasgow in November 2021, where Biden will be hosted by the British Prime Minister. Boris Johnson praised the US President at the spring summit for bringing the USA back to the front lines to fight climate change (Prime Minister's Office 2021 ["PM statement..."]). In the new Atlantic Charter, the leaders agreed that tackling the climate crisis, protecting biodiversity, and sustaining nature would be prioritized in all their states' activities in the international arena (The White House 2021 ["The new..."]). At the inauguration of the 76th session of the UN General Assembly, Biden and Johnson also listed cooperation in the fight against climate change as one of the key tasks for their states and the world. The American President recalled that in April 2021 the USA undertook to double its public international financing to help developing states tackle the climate crisis and announced that this number would be doubled again (The White House 2021 ["Remarks..."]). At Biden's request, the US will allocate more than $\$ 2.5$ billion in 2022 to international climate programs (The White House 2021 ["Budget..."]: 22). The British Prime Minister also noted that the United Kingdom was ready to financially support states struggling with the effects of climate change and recalled that the government paid out $£ 11.6$ billion announced in 2019 (Prime Minister's Office 2021 ["PM speech...”]) . 
It can be said that Boris Johnson is fortunate enough to find in the person of the new American President a worthy partner for cooperation on climate issues. Joe Biden prioritizes green energy and understands much more about global warming or protecting biodiversity than his predecessor. The US and UK leaders seem to be on track to lead the world, together with the European Union, towards reaffirming and strengthening the commitments made under the 2015 Paris Agreement.

\section{The USA and the UK towards the growing influence of China}

Joe Biden wants to strengthen the US position in the international arena, while Boris Johnson aims to present the United Kingdom as an important global actor, regaining a fully sovereign foreign policy after leaving the European Union and being able to make quick, independent decisions. At the Munich Security Conference on February 19, 2021, President Joe Biden called on US allies to unite against China. The United States sees China as not only an economic competitor, but also a threat to cybersecurity or at the level of values such as human rights. His intentions were not shared by the German Chancellor Angela Merkel or the French President Emmanuel Macron². The words of the American leader, however, were supported by the British Prime Minister Boris Johnson, who opposed the repression of the Uighurs in the Chinese province of Xinjiang and supported the people of Hong Kong (Prime Minister's Office 2021). The US and the UK perceive China as the greatest state threat to their economic security. The British government sees the need to cooperate with a state that is becoming more and more powerful in many fields, including in the fight against climate change and biodiversity loss, but above all emphasizes the need to improve the ability to respond to challenges to the security and values of the United Kingdom and its allies (UK Cabinet Office 2021: 22).

Boris Johnson invited South Korea, Australia and India to attend the next G7 summit as guests, which clearly suggests a desire to further consolidate efforts to increase security in East Asia and the Indo-Pacific region, which is a natural zone for China to expand its influence. 15 września 2021 roku Joe Biden zapowiedział utworzenie nowego partnerstwa $\mathrm{w}$ dziedzinie bezpieczeństwa między Stanami Zjednoczonymi, Zjednoczonym Królestwem i Australią (AUKUS), które ma na celu wzmocnienie stabilności w regionie Indo-Pacyfiku

2) Similarly, in the case of the Russian Federation, while France and Germany prefer to ease the sanctions imposed, the United Kingdom shares the US position on maintaining sanctions against Russia (James and Lewis 2021). 
(Madhani and Lemire 2021). On September 15, 2021, Joe Biden announced the creation of a new security partnership between the United States, the United Kingdom and Australia (AUKUS), which aims to strengthen stability in the Indo-Pacific region (Madhani and Lemire 2021). The US and the United Kingdom have pledged to assist Australia in acquiring nuclear powered submarines, which will help the Australian Navy to counter the actions of Chinese units. Boris Johnson said the alliance would allow the three English-speaking maritime democracies to strengthen their relations and sharpen their concentration in this increasingly complex part of the world.

The United States, the United Kingdom and Australia also plan to intensify cooperation in the areas of, among others, cybersecurity, artificial intelligence and quantum technology. These three states, as well as Canada and New Zealand, are already sharing intelligence on this subject thanks to the Five Eyes alliance established in the 1940s. In the new Atlantic Charter, the United States and the United Kingdom announced that they would oppose interfering "through disinformation or other malign influences, including in elections." (The White House 2021 ["The new..."]). No state has been identified as the source of the threat, but most likely these words refer to the activity of the Russian Federation and the People's Republic of China.

\section{DIFFICULTIES IN CURRENT US-UK RELATIONS}

\section{The withdrawal of the United Kingdom from the European Union and a new trade agreement between the UK and the US}

For decades, the European Communities/European Union has been a key American ally. The deepening integration in the Old Continent and the unification of the policies of the EU Member States made it easier for third states to cooperate with them. Nowadays, one agreement can set the terms of trade with about 30 actors, and not with each of them separately, including key states such as Germany, France or, until 2020, the United Kingdom. The UK's withdrawal from the organization in January 2020 caused a number of difficulties not only in the UK's foreign and trade policy, but also in the activities of EU partners. There was a risk that the United States would be torn between good, preferential relations and agreements with the European Union and a special, close relationship with the United Kingdom. As a supporter of multilateralism and international cooperation, Joe Biden views Brexit negatively and would prefer the United Kingdom to 
remain part of a united Europe. In addition, the American President was observing with worry the situation around the emerging border on the island of Ireland, which hindered economic exchange and the free movement of people. He was concerned that the issue of the Northern Ireland Protocol to the Brexit Agreement would undermine the durability of the Good Friday Agreement, which ended the conflict in Northern Ireland in 1998. The President, who repeatedly emphasizes his Irish origin, shows a solicitude for peace in this state. According to CNN's White House correspondent, Joe Biden raised the issue with Boris Johnson in a phone call ahead of the G7 Summit in Cornwall, and US diplomats discussed it with their British counterparts in preparation for the leaders' bilateral talks (Vazquez 2021). While Biden was able to express his private opinion on the protocol in talks with Johnson, American officials assured that the United States was not involved in negotiations or disputes over the protocol, as it is a matter between the government in London and Northern Ireland, and the United Kingdom and European Union.

The renewed commitment of the United States to cooperate with the European Union is not a threat but an opportunity for the United Kingdom. There is a high probability that US-EU and US-British partnership in key areas will be more profitable as US-EU-British cooperation. Some of the planned projects are the restoration of the nuclear deal with Iran and the confirmation and extension of climate commitments at COP26 in November 2021. Combating climate change is a priority for the US, the UK and the EU, so the cooperation of these three important actors will be crucial to the success of the conference.

One of the more difficult aspects of the current US-British relationship is an agreement that is to regulate the terms of trade between the two states. Joe Biden gives it less priority than Donald Trump and is reluctant to comment on it. While five negotiating rounds were held in 2020, the new administration has not yet published the schedule for resuming the negotiation process. The most contentious issues are the provisions on investment, food safety, digital services and pharmaceutical products. The process seems arduous, but it can be assumed that the parties want the most accurate solution possible, given the importance of the agreement and the economic relationship between the states. In 2020, the US exports of goods and services to the UK were valued at $\$ 118$ billion, and the US imports of goods and services from the United Kingdom were approximately $\$ 100.3$ billion. In turn, American foreign direct investments in the UK amounted to $\$ 851.4$ billion in 2019 , and British direct investments in the USA to $\$ 505$ billion (Office of the United States Trade Representative 2020). 


\section{Joe Biden's and Boris Johnson's approaches to development and humanitarian aid, and migration}

Boris Johnson decided to limit the aid provided to other states by the United Kingdom. This does not mean, however, that the government advocating the Global Britain doctrine intends to limit the previously declared shared responsibility for the fate of developing states. The cuts are to be related to the economic consequences of the pandemic for the United Kingdom. Foreign Minister Dominic Raab announced in 2020 that the government would reduce foreign aid spending from $0.7 \%$ of national income to $0.5 \%$ - i.e. by over $£ 4$ billion. While this has led to funding cuts for some programs by up to $85 \%$, Raab said in April 2021 that the UK would be the third largest donor within the G7 as a percentage of GNI (Foreign, Commonwealth \& Development Office 2021). In turn, Joe Biden announced during the opening of the 76th session of the UN General Assembly that the United States wants to be the largest donor of development and humanitarian aid in the world (The White House 2021 ["Remarks..."]). According to Biden's budget request, the US will allocate more than $\$ 10$ billion to humanitarian aid in 2022 (The White House 2021 ["Budget..."]: 23). These funds are to support, inter alia, refugees and victims of conflicts outside the US, and issues of migration to the US from Central America.

Biden expands asylum programs and aims to implement a friendly immigration system, including paving the way for undocumented immigrants to obtain the US citizenship. Boris Johnson is less enthusiastic about migration. The issue of immigrants was one of the hotspots in discussions around Brexit, and the withdrawal of the United Kingdom from the European Union imposed a visa regime in relations with many states. The British government pledges to fight illegal migration and is much less liberal on these issues than the current US administration. However, these are the internal affairs of each state, and it is unlikely that migration policy will constitute any obstacle to the partnership between the US and the UK. The same applies to humanitarian and development aid, especially while dealing with the internal economic effects of the COVID-19 pandemic. The UK is likely to increase funding once the economy has stabilized and, along with the US, will help people in need abroad.

\section{THE FUTURE OF THE SPECIAL RELATIONSHIP UNDER THE JOE BIDEN ADMINISTRATION}

The election of Joe Biden as President heralded a return to old alliances and the US readiness to lead and partner with the participants of the Western world. The personal differences between 
the leaders of the United States and the United Kingdom are relegated to the background in the face of many common challenges and taking collective responsibility for key global activities. US-British relations have a tradition good and strong enough that the differing positions on minor issues will not influence the priorities of the partnership, and the new President understands and appreciates the historical reasons for being close to the United Kingdom. Special relationship is and will be held together by the presence of common threats and global problems. The end of the American presence in Afghanistan, according to the President's announcement, is to enable the US to focus even more on these problems. Both states will cooperate both bilaterally and within the framework of the United Nations, NATO and other international organizations and multilateral agreements. Particular attention should be paid to the recently announced strengthening of cooperation with Australia under AUKUS and other forms of joint engagement in the Indo-Pacific region.

Both leaders take the challenge of climate change very seriously and encourage other states tojoin the fight. TheAmerican administration's agenda in this regard is much closer to the British agenda than it was during the presidency of Donald Trump. The COVID-19 pandemic and its consequences are undoubtedly an important test for the new American administration and for the power ambitions of Johnson's United Kingdom. The two leaders of the West work together to show the world that they can overcome antagonisms and are ready to help any state that needs vaccines or other medical support. Joe Biden and Boris Johnson are aware of China's progressive growth, which will likely be the greatest geopolitical determinant in the 2020s. As close allies in almost every possible field of relationship, the United Kingdom and the United States, whoever will lead them, will need to unite their forces and resources to keep pace with China.

Both states value transatlantic relations, the fullest expression of which is the North Atlantic Alliance. In the new Atlantic Charter, they present themselves as NATO pillars that their allies can always count on. The UK defense spending will increase by $£ 24$ billion over the next four years, making the British defense budget the largest in Europe and the second largest in NATO after the US (Prime Minister's Office 2021). The seemingly fragmented relations (USA-UK, the USA as a part of NATO, USA-European Union) form a network of connections which are the guarantors of European security, based on, inter alia, involvement of the United States in the Old Continent. It is not only close military cooperation, but also in the field of combating non-traditional security threats. 
The withdrawal of the United Kingdom from the European Union is unlikely to have any major negative consequences for BritishAmerican relations. Boris Johnson still prioritizes multilateralism and international cooperation, and the UK authorities spoke negatively about the US withdrawal from the Paris Agreement or the nuclear deal with Iran during the Trump presidency. The UK has left no European allies but is also opening up to other cooperation platforms that it can use to multiply its strength. The independence of political and economic decision-making of the bodies of the European Union is to facilitate and accelerate the activity of the state abroad, enabling it to act on its own, as well as alongside the overseas ally. As Boris Johnson points out, his state's hands are no longer tied in the fight against the world's greatest problems and threats. For example, the possibility of imposing sanctions independent of the EU may make objections to specific regimes real, and thus the readiness to defend the declared values, together with the Americans, such as: liberal democracy, the rule of law, and the free market. The UK government realizes that with the United States open to multilateralism under Biden's presidency, its efforts will find the backing of the greatest ally.

\section{CONCLUSION}

The special relationship between the United States and the United Kingdom has a chance to strengthen thanks to the return of the USA to multilateralism and faith in old alliances, greater UK involvement in the international arena and the presence of international threats in the fight against which the cooperation of the two states is consistent with their national interest. The discussion of both common interests and differences in this article made it possible to understand that common interests and similarities prevail, especially under the Joe Biden administration. In the new Atlantic Charter both leaders emphasized the will to strengthen partnership, recognized the key importance of basing the international order on international law and institutions, and promoting open and fair trade between states. President Biden's willingness that the USA will regain the position of a world leader could be possible thanks to the deepening of the partnership with its allies, especially the UK, which often went hand in hand with the United States in the most difficult moments. Joe Biden and Boris Johnson believe that only international cooperation is able to stop processes dangerous to the globe, such as the COVID-19 pandemic or the effects of climate change. Both states have taken on the burden of at least a partial solution to the world's problems that they want to share with their allies for the common good. 


\section{REFERENCES}

Administration of Joseph R. Biden, Jr. (2021), "Remarks on the Global COVID-19 Response and Vaccination Efforts in St. Ives, United Kingdom", June 10, 2021, [online]. Available at: https://www.govinfo. gov/content/pkg/DCPD-202100495/html/DCPD-202100495.htm [Accessed 16 September 2021].

BBC News (2021), "UK and US relationship indestructible, Boris Johnson says - BBC News", June 11, 2021, [online video]. Available at: https:// www.youtube.com/watch? $\mathrm{v}=\mathrm{Kfcpr} 7 \mathrm{ur} 1 \mathrm{Co} \& \mathrm{ab} \_$channel=BBCNews [Accessed 19 September 2021].

Foreign, Commonwealth \& Development Office (2021), "UK Official Development Assistance (ODA) allocations 2021 to 2022: written ministerial statement", April 21, 2021, [online]. Available at: https:// www.gov.uk/government/speeches/uk-official-development-assistanceoda-allocations-2021-to-2022-written-ministerial-statement [Accessed 16 September 2021].

Fox News (2021), "Biden participates in bilateral meeting with Boris Johnson", September 21, 2021, [online]. Available at: https://www.youtube.com/ watch?v=HpkRdFWoDYs [Accessed 23 September 2021].

Frazin, Rachel (2019), "Biden calls Boris Johnson 'a physical and emotional clone' of Trump", December 13, 2019, [online]. Available at: https:// thehill.com/homenews/campaign/474419-biden-calls-boris-johnson-aphysical-and-emotional-clone-of-trump [Accessed 15 September 2021].

James William, Lewis Simon (2021), "UK, U.S. impose sanctions on Russian intelligence agents over Navalny poisoning”, August 20, 2021, [online]. Available at: https://www.reuters.com/world/uk/uk-sanctionsseven-russian-intelligence-agents-over-navalny-poisoning-2021-08-20/ [Accessed 20 September 2021].

Madhani Aamer, Lemire Jonathan (2021), "Biden announces Indo-Pacific alliance with UK, Australia", September 16, 2021. [online], Available at: https://apnews.com/article/joe-biden-business-china-australia-unitedstates-1b2e597918bc1c8dd1aab26ab32c9621 [Accessed 18 September 2021].

Office of the United States Trade Representative (2020), "United Kingdom", [online]. Available at: https://ustr.gov/countries-regions/europe-middleeast/europe/united-kingdom [Accessed: 16 September 2021].

Prime Minister's Office (2021), "PM speech at the UN General Assembly: 22 September 2021", [online]. Available at: https://www.gov.uk/government/ speeches/pm-speech-at-the-un-general-assembly-22-september-2021 [Accessed 24 September 2021].

Prime Minister's Office (2021), "PM statement at the Leaders Summit on Climate: 22 April 2021", [online speech transcript]. Available at: https:// www.gov.uk/government/speeches/pm-statement-at-the-leaders-summiton-climate-22-april-2021 [Accessed 14 September 2021]. 
Prime Minister's Office (2021), "Prime Minister's speech at the Munich Security Conference: 19 February 2021", [online]. Available at: https:// www.gov.uk/government/speeches/prime-ministers-speech-at-themunich-security-conference-19-february-2021 [Accessed 15 September 2021].

UK Cabinet Office (2021), "Global Britain in a Competitive Age: The Integrated Review of Security, Defence, Development and Foreign Policy", Command Paper 403, March 2021, [online]. Available at: https:// assets.publishing.service.gov.uk/government/uploads/system/uploads/ attachment_data/file/975077/Global_Britain_in_a_Competitive_Agethe_Integrated_Review_of_Security_Defence__Development_and Foreign_Policy.pdf [Accessed 20 September 2021].

Vazquez Maegan (2021), "Boris and Biden: A diplomatic odd couple faces pressure to define the US-UK relationship", June 10, 2021, [online]. Available at: https://edition.cnn.com/2021/06/10/politics/joe-biden-borisjohnson-relationship/index.html [Accessed 14 September 2021].

The White House (2021), "Remarks by President Biden Before the 76th Session of the United Nations General Assembly", [online]. Available at: https:// www.whitehouse.gov/briefing-room/speeches-remarks/2021/09/21/ remarks-by-president-biden-before-the-76th-session-of-the-unitednations-general-assembly/ [Accessed 17 September 2021].

The White House (2021), "Renewing America's Advantages", The Interim National Security Strategic Guidance. March 2021, [online]. Available at: https://www.whitehouse.gov/wp-content/uploads/2021/03/NSC-1v2.pdf [Accessed 14 September 2021].

The White House (2021), "The Budget of the U.S. Government. Fiscal Year 2022", [online]. Available at: https://www.whitehouse.gov/wp-content/ uploads/2021/05/budget_fy22.pdf [Accessed: 17 September 2021].

The White House (2021), “The New Atlantic Charter”, June 10, 2021, [online]. Available at: https://www.whitehouse.gov/briefing-room/statementsreleases/2021/06/10/the-new-atlantic-charter/ [Accessed 18 September 2021]. 


\section{Зузана Пташиьска*}

Универзитет у Варшави - Факултет политичких наука и међународних студија

\section{ИЗАЗОВИ СПЕЦИЈАЛНИМ ВЕЗАМА САД И УЈЕДИҢЕНОГ КРАЉЕВСТВА КРОЗ ПРИЗМУ АКЦИЈА ПРЕДСЕДНИКА ЏОА БАЈДЕНА И ПРЕМИЈЕРА БОРИСА ЏОНСОНА}

\section{Резиме}

Сједињене Америчке Државе и Уједињено Краљевство имају специјалне политичке, економске, војне и културне односе. Нова америчка администрација враћа мултилатерализам и старе савезе међу своје главне приоритете, док су са друге стране британске власти најавиле експанзију свог међународног ангажмана. Ефекти пандемије ковид-19, борба против климатских промена, раст утицаја Кина и претње сајбер безбедности су највећи међународни изазови према виђењу обе државе. САД и УК такође апелују и на друге државе да заједнички преузму одговорност и траже решења за најважније глобалне проблеме. Уједињено Краљевство је напустило Европску Унију у јануару 2020. године и, у складу са реториком владе, повратило суверенитет над својом спољном политиком. Односи две земље би могли да се продубе, али појавиле су се нове невоље, као на пример потреба да се преговара о новом трговинском уговору. Међутим, разлике између Џоа Бајдена и Бориса Џонсона су мање важне у смислу заједничког интереса, као што је видљиво из потписивања нове Атлантске повеље у јуну 2021. године, а такође и у заједничком повећању ангажмана у Индо-Пацифичком региону.

Кључне речи: САД, Уједињено Краљевство, специјалне везе, Џо Бајден, Борис Џонсон

Контакт: z.ptaszynska@student.uw.edu.pl

Овај рад је примљен 13. октобра 2021. године, а прихваћен за штампу на телефонском састанку Редакције, 15. новембра 2021. године. 